\title{
Towards a Cultural Psychology: Meaning and Social Practice as Key Elements ${ }^{*}$
}

\section{Hacia una conceptualización de la Psicología Cultural: significado y práctica como elementos clave}

Received: 14 February 2016 | Accepted: 31 July 2018

\author{
Andrés Santamaría ${ }^{\mathrm{a}}$ \\ Universidad de Sevilla, España \\ ORCID: http://orcid.org/0000-0001-7813-2626 \\ Mercedes Cubero \\ Universidad de Sevilla, España \\ ORCID: http://orcid.org/0000-0003-0417-4246 \\ Manuel Luis de la Mata \\ Universidad de Sevilla, España \\ ORCID: http://orcid.org/0000-0002-9302-4786
}

\begin{tabular}{lll}
\hline a Correspondence & author. & Email: \\
asantamaria@us.es & &
\end{tabular}

How to cite: Santamaría, A., Cubero, M., \& De la Mata, M. (2019). Towards a cultural psychology: Meaning and social practice as key elements. Universitas Psychologica, 18(1), 1-16. https://doi.org/1 0.11144/Javeriana.upsy18-1.tcpm

\begin{abstract}
Several prominent scholars in the Social Sciences have defended the need for a new way of studying the relationship between culture and the individual. Over the last three decades, it has been common to find studies under the heading of Cultural Psychology (CP), which have focussed on the role of culture in historical and ontogenetic development. However, among the defenders of CP, there have been specific disagreements over theoretical and methodological aspects of the project. This lack of agreement is revealed by the different conceptions of the role of meaning and social practice in human psychological functioning. This paper aims is to analyze some different approaches to CP, and the role of meaning plays in its constitution. For us, the central claim of CP is that the human mind should be seen as inter-penetrated by intentional worlds that are culturally and historically situated, and this psychology must to study the ways psyche and culture; person and context, self and other, practitioner and practice live together, and jointly make each other up. In addition, $\mathrm{CP}$ has also identified the symbolic mediation of mind and culture as its analytical focus. Finally, we defend that culture and mind are to be treated as forms of culturally differentiated meaning practices. To make possible this enterprise, we propose the necessity to develop the notion of mediated and situated actions as a unit of analysis of Cultural Psychology.

Keywords

Cultural Psychology; Social practice Meaning; Artifact; Culture.
\end{abstract}

\section{RESUMEN}

Un gran número de destacados autores en Ciencias Sociales han defendido la necesidad de una nueva forma de estudiar la relación entre la cultura y el individuo. A lo largo de las últimas tres décadas, han sido muchos los estudios desarrollados bajo la denominación de Psicología Cultural (PC), que se han venido centrando en el papel de la cultura en el desarrollo histórico y ontogenético. Sin embargo, entre los defensores de la PC ha habido ciertos desacuerdos sobre los aspectos teóricos y metodológicos de este proyecto. Esta falta de acuerdo se ha 
centrado fundamentalmente en las diferentes concepciones del papel del significado y la práctica social en el funcionamiento psicológico humano. El objetivo de este trabajo es analizar algunos enfoques diferentes de PC y el papel del significado en su constitución. A nuestro juicio, la afirmación central de la PC es que la mente humana debería verse como interpenetrada por mundos intencionales que están cultural e históricamente situados. De este modo, esta psicología debe estudiar las formas en las que la psique y la cultura; la persona y el contexto, el yo y el otro, el practicante y la práctica se construyen mutuamente el uno al otro. Así mismo, esta PC destaca la noción de mediación simbólica de la mente y la cultura como su principal interés analítico. Se defiende así que la cultura y la mente deben ser entendidas como formas de prácticas de significado culturalmente diferenciadas. Finalmente, se propone la noción de acción mediada y situada como unidad de análisis de la PC.

Palabras clave

Psicología Cultural; práctica social; significado; artefacto; cultura.

Different views of Cultural Psychology are held about its aims, the questions the discipline should address and, basically, about its very definition and its relation to mainstream psychology. In the following, we shall identify some different approaches to the discipline: Historical-Cultural Psychology (Cole, 1996; Cole \& Engestrom, 1993), the Symbolic approach, represented by Bruner (1990, 1996, 2005) and Shweder (1990; Shweder \& Sullivan, 1993); the Cultural Psychology of Semiotic Dynamics, developed by Valsiner (2014a) and the Symbolic Action Theory, by Boesch and Eckensberger (Boesch, 1996, 1997; Eckensberger, 1996, 2014). However, the recognition of differences between approaches does not mean, as Poortinga (1997) remarks, that they should be considered as incompatible. Instead, they should be viewed as different contributions to the construction of Cultural Psychology (Ellis \& Stam, 2015; Gülerce, 2015). Despite the discrepancies between theorists, they all share a central tenet: "Cultural Psychology is, first of all, a designation for the comparative study of the way culture and psyche make each other up" (Shweder \& Sullivan, 1993, p. 498).

In other words, there is a broad agreement about the idea that any behavior is, by definition, cultural. Any human act is, now it occurs, unavoidably cultural. We could, therefore, say that, in general, all cultural psychologists share the assumption that the goal of Cultural Psychology is to understand how the processes of human development are created and transformed in culture and, in turn, are constrained by culture (Valsiner, 2009).

The main objective of this paper is, therefore, to analyze different approaches to Cultural Psychology, their similarities and differences. From our perspective, these perspectives have enough elements common to justify the consideration of cultural psychology as a (single) discipline. In the first section, we shall look at the similarities in order to develop an integrated view of the cultural approaches. In the second, we shall address the differences that separate these theories from different epistemological frameworks. We shall put particular emphasis on the role that the different approaches assign to meaning about social practice, as this is one of the central differences between them.

\section{Common principles in different cultural agendas}

The cultural approaches we are going to review share the following ideas:

a) An interest in the role of historical and cultural mediation in human psychological functioning. For that reason, these approaches challenge the classical view of cognitive Psychology about the relationship between mind and culture or individual and culture. This non-cultural view understands culture as the medium where actions take place. In other words, culture is interpreted as an independent variable(s) that affects the contents of mind in a causal and mechanistic way and leaves aside its influence in mental processes, which are considered universal. In addition, cultural approaches criticize the view of mind as a set of abstract capacities or cognitive styles that works in a permanent way, regardless of the contexts in which these capacities are used (Bruner, 1990; Cole \& Engestrom, 1993; Eckensberger, 2014; Shweder, 1990; Valsiner, 2014a). 
b) As an alternative, cultural psychologists conceive culture regarding sociocultural activities or practices mediated by cultural tools. As in Vygotsky's psychology, this perspective lets us overcome one of the most frequent and important shortcomings of the theories that stress the role of social influences in psychological functioning. The consideration of culture as the practice of specific individuals in sociocultural settings allows a new way of relating macrosocial or institutional phenomena with psychological processes, escaping from classical "black box" approaches. Culture, conceived in this way, is an intermediate link between the social and the psychological since culture becomes "the product of social life and human social activity" (Vygotsky, 1981, p. 164). Such a concept of culture can be applied to different domains of activity, from the conceptual to those in which the motor aspect is critical. In all cases, what defines the conceptual category of practice is the fact that actions are socially developed. The social dimension of practice and actions refers to the technologies or tools that must be used, to the knowledge that is used and shared and to the goals the participants recognize and pursue (Cole, 1996; De la Mata \& Cubero, 2003; Valsiner, 2014a).

Cultural psychologists propose a view of culture that transcends the physical elements of the environment. For them, the participants create the core elements of culture. These elements include not only the objective dimension of culture but also a subjective or interpretative dimension. Social context and practice encompass, on the one hand, the fixed and stable aspects that exist, regardless of the individual, in other words, the institutional plane. This plane was there before the individual's arrival and will remain after he/she has disappeared. It cannot be interpreted from a realism perspective. The institutional plane does not pre-exit apart from the individuals. It is only created by the individuals that lived before the participants in an activity setting, through the interactions between individuals in this social context. So, we can defend a historical preexistence of culture and not a realistic one.
On the other hand, the practice involves or permits a personal way of being experienced. This last dimension leads cultural psychologists to stress the symbolic nature of culture (Boesch, 1997; Bruner, 1990; Cole, 1996; Shweder, 1990) According to Valsiner, to the extent that signs constitute culture, human behavior -actioncannot be understood outside the meaning systems that make sense of it. Human actions are, therefore, "acts of meaning" (Bruner, 1990, p. 13). Culture is simultaneously inside and outside the individual. More specifically, culture is a psychological process. A process that "comes into being wherever people engage in joint activity over a period of time" (Cole, 1996, p. 301). Or, in Valsiner's words, “...the active process of mediating human lives through signs, both intraand inter-psychologically" (Valsiner, 2014a, p. 47).

c) In a complementary way, they suggest a view of the individual as an active, intentional subject, who is conscious (at least, potentially) of his/her own development and mostly responsible for the creation of the worlds s/he participates in, for his/her own actions and mental objects or representations. The human being is viewed as a person who organizes his/her actions to achieve goals. These goals can be pre-established or concurrent with the act. In other words, the subject is active to the extent that he/she can construct his/her own realities and consciously and intentionally select, from a set of tools, those suitable for the goals proposed.

d) The ideas presented above provide us with an interpretation of mental phenomena as active processes that are located outside the individual's head; as a quality that is not situated in the individual nor culture. Instead, it emerges and is distributed among the elements that participate in this relationship. In other words, mental actions are conceived as mediated by cultural tools and distributed or co-constructed in the sense that they are determined by context and spread among the participants in that context (Boesch, 1997; Bruner, 1990; Cole, 1996; Cole \& Engestrom, 1993; Eckensberger, 1996; Wertsch, 1998, Valsiner, 2014a). There is no global, unique system. Instead, the system of interpretation is 
multiple and depends on the context and on the individuals that participate in that context. From this perspective, cognition implies the action of a subject in a particular context that provides the resources, knowledge, skills, and constraints characteristic of this setting (Rogoff, 1990).

This conceptual perspective leads us to recognize that Cultural Psychology is oriented towards activity settings or practice ${ }^{\mathrm{i}}$. (Ratner, 1996, 2006). The notion of activity setting mediated by tools, especially language, is the link between culture and the individual. In this sense, Boesch (1996), Bruner (1990, 1996) or Cole (1996), for example, speak about situated action and Shweder considers that intentional worlds or objects have no natural reality beyond activities (Shweder 1990). Thus, to the intentional aspect of behavior, they assign: action (Boesch, 1996, 1997; Bruner, 1990; Cole, 1996; Eckensberger, 2014; Hwang, 2014) or its meaning (Bruner, 1990), play the role of connecting link between culture and individual.

e) Authors from different cultural approaches accept an interactive conception of the former relation. From that perspective, it is not possible to understand the individual and his/her actions out of from the cultural setting that they create and that, in turn, gives meaning to them. In the same way, the very existence of culture depends on individuals' actions. Culture develops and changes as a result of individuals' actions and interactions. These authors also argue that mind and culture are the two sides of the same coin. Each one is a fundamental part of the other, as they invent or re-create each other. Put in another way, both sides participate in the genesis of and are the product of the other (Bruner, 1990; Cole, 1996; Eckensberger, 1996; Shweder, 1990; Shweder \& Sullivan, 1993, Valsiner, 2009). Therefore, human action depends on cultural activity and instruments, while at the same time, modify cultural artifacts and practice (Cole \& Hatano, 2007). By not focusing on the individual or culture, but on the person participating in the cultural activity, cultural psychology overcomes both individual and sociological reductionism. Thus, for cultural psychologists, the primary objective is to study the relationship between individual and culture and the way in which these terms interpenetrate their identities and co-construct each other (Esteban, 2011; Santamaría, De la Mata \& Cubero, 2010; Valsiner, 2009).

f) Concerning methodology, cultural psychologists accept that it should depend on theory (and not the opposite). However, there is not a total agreement about the specific methods to be used. All authors assume a non-restrictive view (Cohen, 2007). They do not deny the utility of comparative methods or quantitative analytic procedures (Bruner, 1990; Cole, 1996; Shweder \& Sullivan, 1993; Eckensberger, 1996), but recommend completing these methods with qualitative methodologies, taken from the social sciences. Recently, some theorists propose the importance and the necessity to use mixed-method research strategies (Fisher $\&$ Poortinga, 2018). In this sense, the work of Yanchar and Westerman (2006) provide a fascinating discussion about it. In other words, they suggest the integration of quantitative methods into the post-positivist contextualist paradigm (Dawson, Fischer \& Zachary, 2006). Yanchar and Westerman adopt, as a starting point, a historically-contextual-situated and selfinterpretive view of human mind (as the cultural researches that we are pointing out) and defend the possibility to combining a hermeneutic or interpretative viewpoint harmoniously with quantitative research methodologies (Yanchar \& Weterman, 2006).

Besides the above ideas, all theorists from Cultural Psychology tradition defend the use of historical methods, involving different levels of analysis: microgenetic, ontogenetic and historical-cultural levels —what Cole (1996) labels the meso-genetic method - , as a way of understanding higher mental functions as well as collective mental life (Boesch, 1997; Cole, 1996; Shweder, 1990; Vygotsky, 1986). The very fact that cultural psychologists confer mental processes a cultural and historical nature justifies the interest and the need to study them from a genetic perspective ${ }^{\text {ii }}$. In other words, all these authors are interested in studying these phenomena in their processes of change. 
This analytical perspective implies examining the mechanisms of genesis, formation, and transformation of a given phenomenon to its final state. This genetic approach was also defended by Wundt and by all the German tradition (Jahoda, 1992; Cole 1996). It has become a key piece in all the methodological proposals of Cultural Psychology.

\section{(Some) Differences between cultural agendas}

From our perspective, besides the similarities, there are significant differences between different proposals within the field of Cultural Psychology. The most important differences may be found between an anthropological perspective, such as the symbolic approach by Shweder, and a psychological view of the discipline, such as Cole's Historical-Cultural psychology and Valsiner's cultural psychology of semiotic dynamics. The approaches adopted by Bruner and the School of Saarbrücken may be located on either side, depending on which aspects are analyzed.

a) The first difference pointed out by Jahoda (1992, 2012), is the relationship between Cultural Psychology and mainstream Psychology. According to Jahoda, this difference conditioned the evolution of the different approaches significantly. Cole (1996) considers culture as an "action field". For him, culture is the basic context where the human being learns and develops. In this context, all actions take place and make sense. For that reason, he claims that all psychology should be cultural. For this proposal, therefore, the status of Cultural Psychology is similar to that of general psychology as he does not consider Cultural Psychology an area, or a specialized field, but a way of doing Psychology (Cole, 1996). Shweder, in contrast, defends the view that cultural psychology is a branch of psychology devoted to the study of cultures and the mentalities associated with them. For that reason, it is complementary to other related fields in psychology, such as Cross-Cultural or Social Psychology and other disciplines like Anthropology or Ethnography. (Shweder, 1990; LeVine, 2007). Wundt's Second Psychology directly influences Shweder's position about the place of Cultural Psychology about mainstream Psychology. For Wundt, Second Psychology does not exhaust the study of psychological phenomena. Perhaps because of these differences, Cole focuses on the study of general aspects of culture and cognition in context, while Shweder is interested in the analysis of specific cultures and mentalities. In this case, Boesch (1997) and Bruner $(1990,1996)$ adopt Cole's perspective. Valsiner's position about this issue is, in general, similar to Cole, as he assumes the centrality of culture "We study phenomena we call "cultural" in human psychology in order to make sense of general principles of the human psyche that cannot be explained by principles of lower levels of generality" (Valsiner, 2014c, p. 154).

b) However, an in-depth analysis of aspects such as the status of symbolic phenomena and meanings related to social practice reveals one of the most important differences between these approaches. That is, the methodological approach of each one is entirely different. For Shweder and Bruner, for example, culture is conceived as a meaning system. Individuals create meanings in interaction. Culture has no real existence out of these meanings. We may say that, for the symbolic approach, both culture and social practice cannot be explained, but interpreted. This idea led authors to claim the interpretive character of Cultural Psychology (Bruner, 1990; Shweder, 1990). Related to this idea, they do not intend to use practice as the guiding principle of the human mind, but to understand practice by using hermeneutic or interpretive methodologies. In this sense, the Symbolic Action Theory agrees in defense of the interpretive character of Cultural Psychology and the need to use hermeneutic methods to analyze this kind of Psychology (Krewer, 1990).

In general, Cole and the approach of cognition in context focus on the analysis of cognition in the practice in which it takes place. It makes him/them assume that psychological functioning depends on social, 
material and ideological (regarding Ilenkov) dimensions that define practice. For Cole, practice plays the role of the guiding principle of human behavior. He defends, thus, the explanatory character of cultural psychology and the use of methodologies such as systematic observation, the evolutionary-historical method or even quantitative methodologies. All these methodologies are far from hermeneutic methods. So, although Cole recognizes the symbolic nature of both cognition and practice, he does not emphasize this feature over others. The role of the semiotic aspect is not central to his approach.

In this sense, in Vygotsky's original project and in its developments by authors like Tulviste (1991), Wertsch $(1981,1998)$ or Valsiner $(2009$, $2014 \mathrm{~b}$ ), we find some elements that enable us to account for the way in which human actions are semiotically mediated without separating them from their activity contexts (Brescó, 2016). The key to this assertion is the recognition of the instrumental nature of signs. This feature makes it possible to conceive both the ideal and material dimension of mental actions. The importance of giving a different status to the meaning and social practice is central as it determines the very notion of Cultural Psychology as an interpretive or explanatory science. It also determines the methods and techniques more suitable for the construction of the discipline. This is the third difference between the two main approaches to Cultural Psychology. In the next section, we shall analyze this issue in greater detail, as it is the focus of this article.

\section{The role of meaning and practice}

Undoubtedly, one of the most crucial phenomena in our everyday experience is language. Language becomes a critical element of human cognition. Almost all human cognitive activities and cultural practices are based on language. The central feature of all these activities and practices is their symbolic nature and, therefore, their meaningfulness. However, the notion of meaning is too vague. For that reason, it would be useful to clarify this notion of enabling us to analyze the role that meaning (and practice) play in the constitution of Cultural Psychology (Santamaría et al., 2010). We shall do this briefly now.

Over the last two decades, a more dynamic approach to meaning has been developed. The central idea in this approach is that meaning must be considered concerning the practices in which it is used (Bruner, 2005; Cole, 1996). From this perspective, the mind cannot be conceived just as a capacity to solve problems. Instead, it must be viewed as the capacity to enter a shared world of meaning. From traditional and objectivist approaches, the meaning is defined in terms of the relationship between abstract symbols and the state of affair in the world, between signs and their referents. From this perspective, meanings, concepts, deductive models and, in sum, all aspects of rationality are characterized by their universality and independence from culture and context. However, from other positions, meaning is not just a fixed relation between sentences and an objective reality, as objectivism holds. Instead, meaning is in between symbols and the world; an event of cultural and historical ownership. Let us say that meanings are public property. For that reason, we argue that meaning is not in the head of the individual but flows in social interchanges. Meaning is not only an expression of oneself, but is inherently shared or, in Valsiner's (2014a) terms, co-constructed. It constitutes and modulates the public space in which we develop our activities and relate to others (Nedergaard, 2016; Simão, 2016).

In this sense, following Budwig, Uzgiris and Wertsch (2000) we can identify four approaches to the study of meaning and meaning construction that differ from classical and objectivistic views.

a) Dialogic approaches based on the work by Bakhtin (1986). They focus especially on the analysis of utterances. From this perspective, speech always implies an irreducible tension between a semiotic system and the particular use of that system (Gülerce, 2014; Zittoun, 2014, 2018). Speech is conceived as a form of action. 
b) Sociological and Conversational Analysis approaches. This field of study emerges from ethnomethodology and other views of speech as situated practice (Schegloff, 1991). Meaning is considered in its use as a communicative practice. The emphasis is put on communication (rather than on utterance) as a form of action (Goodwin \& Goodwin, 1992). It looks at how communication is structured in different everyday practices.

c) Functional and Cognitive Linguistics approaches. Meaning is considered in relation to its context of use (Tomasello, 1998). These approaches emphasize the instrumental character of language. Language is seen as a tool for cognition. Differences with other approaches appear when defining the context.

d) Anthropological Linguistics approaches. Linguistic anthropologists, as well as functionalists, focus on the study of the key issues in meaning construction. As conversational analysts, they emphasize the importance of communicative practice and the idea that linguistic productions are "social facts".

These different approaches presuppose a more flexible, dynamic and constructive view of meaning than the classical ones. They enable the development of theories of meaning that focus on the connection with the social practices which individuals are embedded in. This relation is established not only through mediational but also through symbolic means. Our interest coincides with other researchers in Cultural Psychology and focuses on analyzing the way individuals appropriate cultural practices and meanings in specific activity settings. It implies a view of meanings as elements involved in practice. Although this view is usual in interdisciplinary discussions about language and thought, it has only recently become relevant in psychology. The ideas outlined above demonstrate that the main agendas in Cultural Psychology share the idea that human mental functioning is an emergent property of symbolically mediated experiences and historically developed meanings and practices.
The approach adopted by Shweder and Bruner is inspired by the anthropological ideas of Geertz (1973). Two aspects of Bruner and Shweder's proposals reflect this influence. On the one hand, they can be considered inheritors of Geertz's notion of culture, while on the other, because of assuming this notion, they defend a conception of Cultural Psychology as an interpretive discipline. Let's examine these two issues. Geertz was one of the main responsible for a change in the way of analyzing culture in Anthropology. For Geertz, culture is a meaning system that is mostly responsible for the constitution of human beings as such, of the very category of human being:

(Culture) "...denotes a historically transmitted pattern of meanings embodied in symbols, a system of inherited conceptions expressed in symbolic forms, by means of which men communicate, perpetuate, and develop their knowledge about, and attitudes toward life". (Geertz, 1973, p. 89)

Taking Geertz's standpoint, Bruner and Shweder assume that culture can be defined as a symbolic context, as a meaning system that makes sense of human actions (Greenfield, 2009). Bruner $(1990,1996)$, for instance, maintains that human acts cannot be understood or studied out of their meanings. They are, by definition, "acts of meaning". He considers that individual and culture relate to each other through meaning. Culture shapes the individual mind, through meaning creation. This process of meaning creation implies situating individual's encounters with the world in their appropriate cultural contexts. For Bruner (1996), although meanings are in mind, their origins must be in culture, since individuals cannot create them without the symbolic systems developed in their culture. Thus, Bruner argues that meaning is not constructed after the act. Instead, human actions are, from the very moment they are produced, acts of meaning. In other words, they are inextricably linked to an interpretation. This interpretation is not merely individual, but generated in culture, in communicative interchanges with others. These interchanges 
occur under the belief that the interlocutors share a common world.

Meaning is always meaning for a person or community. Words have no meaning on their own. They only have meaning for the persons that use them to mean something. Thus, the meaning is always a matter of relation. Authors like Bruner (1990) stress that meaning is a culturally mediated phenomenon. Its existence depends on a previous system of shared symbols. We are therefore faced with the question: How can we construct these shared meanings? In recent years, a great deal of research has evidenced that humans recognize and understand intentional behavior regarding narrative. They understand narrative as a mode of thinking, as a way of creating and interpreting meaning. Narrative has been identified as the central means by which people attribute meaning to life events. As Bruner (1996) would have put it, humans are born with a disposition to narrate, to tell stories to one another. Humans learn to narrate, and in so doing, they learn to remember their past and to imagine their future. They learn to order action sequences to make a whole that can be shared with another person. Bruner (1996) argues that narrative lets us give sense to and organize our experiences and the meanings shared with individuals in our social and cultural context. As we can see, Bruner's conception of narrative goes beyond the temporal perspective of action to incorporate what he calls the "landscape of consciousness" (Bruner, 1996, p. 23); that is, the interpretation that humans make of actions and events in terms of goals, motivations, intentions, beliefs, values, etc.

This led Bruner (1990) to consider narrative as the best means for studying cultural meaning. For this author, the narrative is a way of interpreting the world regarding actors with intentions and purposes, making them perform actions in certain settings by using particular tools or resources. It is, therefore, an intrinsically cultural way of thinking. Socially constructed narratives as organizers of our experiences and practices are a central focus of the kind of meaning accounts that we are developing in this paper. According to this view, narrative constructions developed in collaboration with others provide a structure for a personal and social meaningful experience. In sum, it is a cultural category that emphasizes meaning construction.

From a similar position to Bruner's, Shweder argues that human beings are subjects continuously involved in a search for meanings (Shweder, 1990). With this expression, Shweder and his colleagues mean that humans are especially motivated toward appropriating meanings and resources or our cultural environment. For them, as for Bruner, meanings are unavoidably social.

As we have claimed, Geertz has influenced both Bruner and Shweder. This influence has conditioned their visions about the role of symbolic issues and their view of Cultural Psychology as an interpretive discipline. From this perspective, Cultural Psychology is not interested in explaining the universal and differential aspects of the human mind. Instead, its interest lies in accounting for the social conditions and cultural models that are responsible for the meanings ${ }^{\text {iii }}$ and senses that individuals give to their actions to make them understandable and explicit. This interpretive view is directly associated with the defense of methodologies of comprehensive nature. Krewer (1990) calls them dialogic-hermeneutic methods. This methodological conception has a phenomenological orientation and concentrates on making sense of human actions in cultural contexts (Brescó and Wagoner, 2016). However, as it would not be right to conclude from the above words that symbolic approaches do not contemplate the activities in which human actions take place, we cannot refer to Cole's Historical-Cultural Psychology by saying that it does not consider the importance of meaning for individual actions. Instead, the difference between the two approaches lies in the emphasis they put on one aspect or the other. Of course, this does not lessen the importance of this difference. Cole's perspective, inspired by Vygotsky's and Luria's Historical-Cultural Psychology, is substantially different; his analysis focuses on activity ${ }^{\text {iv }}$. 
Cole's position about this specific medium of human life, cultural activity or practice and how it influences psychological functioning can be summarized as follows:

"...culture as a system of artifacts and mind as the process of mediating behavior through artifacts in relation to a supra-individual "envelope" with respects to which object/environment, text/ context are defined. This approach allows me to make use of the notion of culture as medium and of context as both that which surrounds and that which weaves together. It also provides me with a basic unit of analysis that has natural linkages to the macro pole of society and its institutions and the micro level of individual human thought and actions". (1996, p. 143)

This notion of the artifact was originally developed by the Soviet philosopher Edvald Ilenkov who proposed it to provide a materialist explanation of "the ideal". By using this term, Ilenkov refers to all non-material phenomena as mental processes (subjective ideality) but also to objective non-material phenomena such as the various types of value and meaning and other properties, like hospitality or dangerousness. It is interesting to note that for Ilenkov mental phenomena are not the primary form of the ideal. The subjective ideality is a secondary realm of phenomena. It derives from the primary realm, consisting of meanings and values (and the other forms of objective ideal phenomena). To account for the way in which the objective ideal becomes constituted and how this form of ideality gives rises to the other one, Ilenkov developed the notion of artifacts (Norros, 2018). Artifacts are embodiments of human activity. In the artifact, the natural object acquires significance (original emphasis).

The notion of artifacts provides a model for understanding all forms of value and meaning, including linguistic meanings (Brinkmann, 2016; Innis, 2016). Words are configurations of sounds that acquire their significance because of their incorporation into human practices. Words are artifacts for Ilenkov. "The meaning of a word is an ideal form acquired by a purely natural object through its incorporation into purposeful human activity. A word owes its significance to its use" (p. 185).

For Cole, (1996), Ilenkov's notion of artifact is closely related to Vygotsky's idea of a tool. It was Vygotsky who proposed the study of tools as a way of studying cultural history, as they are products of it. Cole understands that human beings live in a world that is transformed by artifacts, which in turn were constructed and used by the preceding generations. The main function of artifacts is to coordinate human beings with their physical and social milieu (1995a). This concept is related to both culture and cognition. On the one hand, artifacts are the main constituents of culture. On the other, the mind emerges from the interaction between subjects, artifacts and the world of objects (Cole, 1996; Cole and Engestrom, 1993). This is the basic mediational triangle and allows us to formulate the cultural determination of individual psychological functions and, in general, to relate mind and culture in an integrated schema.

Cole stresses the idea that artifacts do not exist in the vacuum. Instead, they exist about an activity setting or system. This system integrates subjects, objects, and artifacts (material and psychological) in an integrated whole (Cole and Engestrom, 1993). Moreover, Cole, relying on Engestrom's conceptualization of activity, includes the following elements as basic components of the activity systems:

- The set of individuals related through a common objective (community).

- The norms, rules and conventions that regulate the relations between individuals and between the individuals and their actions.

- The division of goal-directed actions between the members of the community (a division of labor).

All these elements and the complex relations between them can be continuously re-invented as products of the life and history of human beings (Cole, 1996). This view of activity systems extends the subject-artifact-object basic mediational triangle, which represents the basic structure from which human cognition emerges. 
The notion of activity setting that derives from the theory proposed by Cole and Engestrom allows to understand it as the medium in which the subject interacts, as the product of human actions in that medium and, finally, as a prerequisite for the very existence of human actions (Cole, 1996). The main consequence of this view of mediated activity setting is that it affects simultaneously the subject in his/her relationship with the context or with other subjects and the context where the subject interacts.

This conceptualization of activity and its systems of relation leads Cole to consider that activity can play the role of the object of study of human behavior. Moreover, the assumption of this basic unit of analysis allows him to defend a view of Cultural Psychology as an explanatory science. This discipline needs, in his view, some specific methodological tools to be constructed, because Cole's methodological view does not imply abandoning classical empirical approaches, but the high level of artificiality that characterizes the situations they analyze. Therefore, Cole recommends the use of tools and techniques developed by authors in the Cognition in practice approach. That is, tools for analyzing the everyday activity of the individual in real-life contexts (Lave, 1993; Lave y Wenger, 1991; Rogoff, 1990). For that reason, Cole and the Cognition in Context theoreticians, defend the need to perform research with ecological validity. The contexts, processes, and tasks should be significant for participants; they should be recognizable as examples of situations in which they usually participate (Norros, 2018).

Valsiner's position on these issues lies between that of Bruner and Shweder, on the one hand, and Cole's approach, on the other. Regarding the notion of culture, Valsiner claims for consideration of culture as a process of semiotic mediation. Yet this author recognizes the existence of an objective (or structural) dimension of culture, instead of defining culture as a system of meanings, the focus of his approach is the analysis of the processes by which human beings mediate their conduct (to use Valsiner's term) through meaning creation and use (Valsiner, 2014a). About the methodology, Valsiner tries to go beyond the dichotomy of explanation versus interpretation. In this vein, he advocates for considering psychology as an "ideographic science", based on the "inevitable uniqueness of psychological phenomena" (Valsiner, 2014a, p. 256). However, this consideration does not imply a renounce to generalization. This notion of generalization is not based on the relation between the observed phenomenon and an "average case", but "...on the principles that govern the emergence of ever new uniqueness" (p. 257). Hence, what must be general are the processes, not the cases, which, by definition, are always unique. These principles are principles of semiotic meditation for Valsiner.

\section{Final remarks: meaning as a key element in the constitution of a Cultural Psychology}

The analyses presented above let us conclude that Cultural Psychology focuses on the processes through which contexts, practices and meanings become essential and active components of psychological development. Cultural Psychology insists that practices and meanings are essential aspects of psychological systems and not simple external conditions of influence. This consideration allows us to distinguish Cultural Psychology from other forms of Psychology, some of them labeled as contextual or situated, like Discursive Psychology (Edwards, 1995), Cognition in Context Psychology (Lave, 1993).

So far, we have defended psychology of meaning that puts special emphasis on the intentional dimension of the subject, as an agent of his/her behavior and embedded in the cultural practices $s /$ he is involved in through development. This position can be included within a more general approach that defends the confluence of Psychology and the Social Sciences around an intentional view of subject and consciousness (Cole, 1996; Frawley, 1997; Geertz, 1973, 1996; Shweder, 1990). This view is at the basis of some projects of Cultural Psychology (Santamaría et al., 2010; Bruner, 
1990, 1996; Cole, 1996; Shweder, 1990; Valsiner, 2009).

Cultural Psychology, like other approaches, conceives human beings as intentional subjects, a subject that is biological, social, historical and cultural. This subject can create and transform knowledge through action in sociocultural settings. From this perspective, the notion of semiotic mediation developed by Vygotsky provides the basis for understanding the way in which the subject is constituted and allows us to account for the relationship between knowledge, meaning and action. Finally, we would like to remind that, as psychological processes are embedded in culture, they are organized around the processes of meaning construction and use. These processes link the human being and culture together. As Bruner (1990) remarks, because of our participation in culture, meaning is public and shared and, in this way, the mind is connected to culture.

However, while all cultural psychologists recognize the importance of the notions of meaning and action, some differences do exist between authors and approaches in the specific consideration they give to these concepts. For example, Cole's view of Cultural Psychology contrasts with the position defended by authors like Swheder and Bruner, which conceives culture as a web of meanings. By defending that these meanings cannot be explained, but interpreted from another net of meanings, these authors place meanings at the forefront as frames for interpreting the world. Each culture becomes an "autonomous" meaning system (in a similar way to any language). This meaning system cannot be explained, but translated into another system (another culture), in the same sense as one language can be translated into another. Social practice must be analyzed through those meanings, which, in turn, acquire a constituent role in practice, instead of being conceived as the explanation of meanings. This issue presents us with the most important differences between Cole's position and those of other authors. For Cole, semiotic aspects are not as central as in Shweder and Bruner's account ${ }^{\mathrm{v}}$. He argues that practice provides the frame for human cognition.
Meanings are constituents of practice, but they are not considered such a central part of it.

In our opinion, Cultural Psychology must develop towards increasing integration of the two elements: meaning and practice. This integration would enable us to expand on Vygotsky's original project (Ratner, 2017). Since his work was based on a strong commitment to the Marxist philosophical tradition, the task that he assumed was to develop an explanation of human mind and, consequently, of its symbolic activity, based on social practice. This practice is rooted in the material conditions of human existence. This conception is associated to the idea that to overcome the "historical crisis of Psychology" (Vygotsky, 1987) it is necessary to build a science that can explain human mind by bridging the gap between an explanatory psychology, focused on elementary psychological processes, and an interpretive psychology of higher mental processes, thereby providing room for culture (Marsico, 2015).

\section{Looking for a unit of analysis: going forward}

As some scholars defend, the main aim of a Cultural Psychology is centered on understanding how the mind is related to cultural, social, institutional, and historical context. In front of the traditional tendency to study each part of psychological phenomena (individual and culture) isolated, Cultural Psychology intends to develop a view that considers the different dimensions involved and the interrelationships among these. For this purpose, we think it is necessary to develop an appropriate unit of analysis for psychological phenomena. In this sense, our proposal is oriented to developing a theoretical and analytical strategy that goes beyond a limited focus on individual mental functioning versus social, historical context (culture). Such a theoretical and analytical strategy will let us overcome the idea that meaning is inside our heads and our practices have nothing to do with meaning. 
From our view, Cultural Psychology must not be only a Psychology of meaning (symbolic nature of individual and culture), but neither a Psychology of practices (mere activity). Both meaning and practice are inextricably related (Santamaría et al., 2010). So, we must find a way to link these perspectives (this kind of Cultural Psychology) without reducing one to another. We assume that socio-cultural research should combine the development of theoretical concepts about mind and culture with methodologies to study them. That is, we need to develop units of analysis to expand the assumptions of socio-cultural theory into the empirical plane. With regard to this issue, we share the arguments defended by authors like Vygotsky, Zinchenko and Wertsch, among others, about the relevance of mediated action as the unit of analysis for the study of higher mental functions (Zinchenko, 1997). But, why mediated action?

1. Transcend the border between the individual and the social. It permits to study both the intra and the intermental processes. Action can be performed both by an individual and a group.

2. Provides a natural link between action (including mental actions) and the cultural-institutional and historical context in which action develop.

3. Breaks the gap between the external and the internal and the social and the individual.

As Wertsch (1998) claims, it is crucial for sociocultural research to formulate a theoretical and methodological position that let us overcome the antinomy between the individual and the social. We think that the specific approach based on mediated action let us solve this antinomy. The reasons for this are the following:

1. - because it let us develop a focus on the agent-instrument dialectics.

2. - because it provides us important insights into other relevant dimensions of action: scene, tools, goals, purpose, etc.
For these reasons, we defend mediated and situated action as the unit of analysis of psychological processes. Action reflects the cultural and individual dimension of the human cognition. Moreover, it can serve as the unit of analysis of processes that are taking place both in the interpsychological and the intrapsychological plane. At the same time, action allows us to incorporate the semiotic (meaning) dimension of mind in a broader system. Finally, action links activity settings, modes of discourse and ways of thinking.

\section{References}

Bakhtin, M. M. (1986). Speech genres and other late essays. C. Emerson \& M. Holquist (Eds.). Austin: University of Texas Press.

Boesch, E. (1996). The seven flaws of Crosscultural Psychology. The story of a conversion. Mind, Culture and Activity, 3(1), 2-10. https://doi.org/10.1207/s153278 $84 \mathrm{mca} 0301 \_2$

Boesch, E. (1997). Reasons for a symbolic concept of actions. Culture and Psychology, 3(3), 223-231. https://doi.org/10.1177/135 $4067 \times 9733012$

Brescó, I. (2016). Between history and cultural psychology: some reflections on mediation and normativity when reconstructing the past. Culture and Psychology, 22(3), 414-423. https://doi.org/10.1177/1354067 X16645294

Brescó, I., \& Wagoner, B. (2016). Context in the cultural psychology of remembering. In C. Stone \& L. Bietti (Eds.), Contextualizing human memory (pp. 69-85). London: Routledge.

Brinkmann, S. (2016). Cultural psychology and its values. Culture and Psychology, 22(3), 376-386. https://doi.org/10.1177/1354067 X16645293

Bruner, J. (1990). Acts of meaning. Cambridge, Mass.: Harvard University Press.

Bruner, J. (1996). Meaning and self in cultural perspective. In D. Bakhurst \& Ch. 
Sypnowich (Eds.), The social self (pp. 18-29). London: Sage.

Bruner, J. S. (2005). Cultural psychology and its functions. Constructivism in the Human Sciences, 10, 53-63. Retrieved from https://search.proquest.com/openvie w/fa90120b9bc9224d8349337bc6049c0f/1 ?pq-origsite $=$ gscholar $\& \mathrm{cbl}=29080$

Budwig, N., Uzgiris, I. C., \& Wertsch, J. V. (Eds.). (2000). Communication: An arena of development. Stanford, Conneticut: Ablex Publishing Corporation.

Cohen, D. (2007). Methods in cultural psychology. In S. Kitayama \& D. Cohen (Eds.), Handbook of cultural psychology (pp. 196-236). New York, NY: The Guilford Press.

Cole, M. (1996). Cultural Psychology: a once and future discipline. Cambridge: Harvard University Press.

Cole, M., \& Engestrom, Y. (1993). A cultural-historical approach to distributed cognition. In G. Salomon (Ed.), Distributed Cognitions: Psychological and Educational Considerations (pp. 1-46). New York: Cambridge University Press.

Cole, M., \& Hatano, G. (2007). Culturalhistorical activity theory: Integrating phylogeny, cultural history, and ontogenesis in cultural psychology. In S. Kitayama \& D. Cohen (Eds.), Handbook of cultural psychology (pp. 109-135). New York.: The Guilford Press.

Dawson, T. L., Fischer, K. W., \& Zachary, S. (2006). Reconsidering qualitative research approaches: A cognitive developmental perspective. New Ideas in Psychology, 24(3), 229-239. https://doi.org/10.1016/j.newidea psych.2006.10.001

De la Mata, M., \& Cubero, M. (2003). Psicología Cultural: aproximaciones al estudio de la relación entre mente y cultura. Infancia y Aprendizaje, 26(2), 181-199. https://doi.org /10.1174/021037003321827777

Eckensberger, L. (1996). Activity and action: two different roads towards an integration of culture in psychology? Culture and
Psychology, 1(1), 67-80. https://doi.org/10.1 177/1354067X9511005

Eckensberger, L. (2014). Integrating the Emic (Indigenous) with the Etic (Universal). A case of squaring the circle or for adopting a culture inclusive action theory perspective. Journal for the Theory of Social Behaviour, 45(1), 108-140. https://doi.org/10.1111/jts b. 12057

Edwards, D. (1995). A commentary on discursive and culture psychology. Culture and Psychology, 1(1), 55-66. https://doi.org/10.1 177/1354067X9511004

Ellis, B. D., \& Stam, H. J. (2015). Crisis? What crisis? Cross-Cultural psychology's appropriation of cultural psychology. Culture and Psychology, 21 (3), 293-317. http ://dx.doi.org/10.1177/1354067X15601198

Esteban, M. (2011). An interpretation on cultural psychology: Some theoretical principles and applications. Suma Psicológica, 18(2), 65-88. Retrieved from https://www.redalyc.org/pdf/1342/134 222985006.pdf

Fisher, R., \& Poortinga, Y. H. (2018). Addressing methodological challenges in culturecomparative research. Journal of CrossCultural Psychology, 49(5), 691-712. https:/ /doi.org/10.1177/0022022117738086

Frawley, W. (1997). Vygotsky and Cognitive Science: Language and the Unification of the Social and Computational Mind. Cambridge, MA: Harvard University Press.

Geertz, C. (1973). The interpretation of cultures. New York, NY: Basic Books.

Geertz, C. (1996). Los usos de la diversidad. In N. Sánchez Durá (Ed.), Clifford Geertz. Los usos de la diversidad (pp. 65-92). Colección: Pensamiento Comtemporaneo, 44. Barcelona: Paidós e I. C. E. de Barcelona.

Greenfield, P. M. (2009). Linking social change and developmental change: shifting pathways of human development. Developmental Psychology, 45 (2), 401-418. h ttps://doi.org/10.1037/a0014726

Goodwin, C., \& Goodwin, M.H. (1992). Assessments and the Construction of 
Context. In A. Duranti, \& C. Goodwin (Eds.), Rethinking Context: Language as an Interactive Phenomenon (pp. 147-189). Cambridge: Cambridge University Press.

Gülerce, A. (2014). Before and beyond dialogicality: Transformative trialectics of human dialogues. New Ideas in Psychology, 32, 88-98. https://doi.org/10.1016/j.newide apsych.2013.05.004

Gülerce, A. (2015). The "\&" has emerged. Seeking "culture" and "psychology" for Culture \& Psychology. Culture and Psychology, 21(4), 455-468. https://doi.org/ 10.1177/1354067X15615800

Hwang, K. K. (2014). Culture-Inclusive Theories of Self and Social Interaction: The Approach of Multiple Philosophical Paradigms. Journal for the Theory of Social Behaviour, 45(1), 40-63. https://doi.org/10. $1111 /$ jtsb. 12050

Innis, R. E. (2016). Between philosophy and cultural psychology: Pragmatist and semiotic reflections on the thresholds of sense. Culture and Psychology, 22(3), 331-361. https://doi.org/10.1177/1354067 X16638847

Jahoda, G. (1992). Crossroads between culture and mind. Continuities and Change in Theories of Human Nature. New York: NY. Harvester Wheatsheaf. Retrieved from https://lib.uge nt.be/catalog/rug01:000271238

Jahoda, G. (2012). Critical reflections on some recent definitions of "culture". Culture $\mathbb{E}$ Psychology, 18(3), 289-303. https://doi.org/ 10.1177/1354067X12446229

Kozulin, A. (1986). The concept of activity in Soviet Psychology. Vygotsky, his disciples and critics. American Psychologist, 41(3), 264-274. http://dx.doi.org/10.1037/0003-0 66X.41.3.264

Krewer, B. (1990). Psyche and culture: Can a culture-free psychology take into account the essential features of the species, homo sapiens? The Quarterly Newsletter of the Laboratory of Comparative Human Cognition, 12(1), 24-36.

Lave, J. (1993). The practice of learning. In S. Chaiklin \& J. Lave, (Eds.): Understanding practice. Perspectives on activity and context (pp. 229-237). Cambridge: Cambridge University Press.

Lave, J., \& Wenger, E. (1991) Situated learning. NY: Cambridge University Press.

Leont'ev, A. N. (1979). The problem of activity in psychology. In J. V. Wertsch (Ed. and Trans.), The concept of activity in Soviet psychology (pp. 37-71). Armonk, NY: Sharpe.

LeVine, R. A. (2007). Anthropological foundations of cultural psychology. In S. Kitayama \& D. Cohen (Eds.), Handbook of cultural psychology (pp. 40-58). New York, NY: The Guilford Press.

Marsico, G. (2015). Striving for the new: Cultural psychology as a developmental science. Culture and Psychology, 21(4), 445-454. https://doi.org/10.1177/1354067 X15623020

Nedergaard, J. (2016). Theory of Semiotic Skin: Making sense of the flux on the border. Culture and Psychology, 22(3), 387-403. htt ps://doi.org/10.1177/1354067X16650121

Norros, L. (2018). Understanding acting in complex environments: Building a synergy of cultural-historical activity theory, Peirce, and ecofunctionalism. Mind, Culture, and Activity, 25(1), 68-85. https://doi.org/10.10 80/10749039.2017.1350714

Poortinga, Y. H. (1997). Towards convergence? In J. W. Berry, Y. H. Poortinga \& J. Pandey (Eds.), Theory and method (pp. 347-87). Vol. I of Handbook of cross-cultural psychology (2nd ed.). Boston, MA: Allyn and Bacon.

Ratner, C. (1996). Activity as a key concept for Cultural Psychology. Culture and Psychology, 2(4), 407-434. https://doi.org/10.1177/135 4067X9600200404

Ratner, C. (2006). Cultural Psychology: A Perspective on Psychological Functioning and Social Reform. Mahwah, NJ: Lawrence Erlbaum Associates.

Ratner, C. (2017). The discrepancy between macro culture and individual, lived psychology: An ethnographic example of Chinese moral behavior. Culture and 
Psychology, 23(3), 356-371. https://doi.org/ $10.1177 / 1354067 X 16658021$

Rogoff, B. (1990). Apprenticeship in thinking. Cognitive development in social context. New York, NY: Oxford University Press.

Santamaría, A., De la Mata, M. L., \& Cubero, M. (2010). Thinking as action: Theoretical and methodological requirements for cultural psychology. Theory EB Psychology, 20(1), 76-101. https://doi.org/10.1177/095 9354309350244

Schegloff. E. (1991). Conversation Analysis and Socially Shared Cognition. In J Resnick L. an Levine, S Teasley (Eds.), Perspectives on Socially Shared Cognition (pp. 150-171). American Psychological Association.

Shweder, R. A. (1990). Cultural Psychologywhat is it? In J. W. Stigler, R. A. Shweder \& G. Herdt (Eds.), Cultural Psychology. Essays on comparative human development (pp. 27-66). Cambridge: Cambridge University Press.

Shweder, R. A., \& Sullivan, M. A. (1993). Cultural psychology: Who needs it? Annual Review of Psychology, 44, 497-527.

Simão, L. M. (2016). Culture as a moving symbolic border. Integrative Psychological $\mathbb{E}$ Behavioral Science, 50(1), 14-28. https://doi .org/10.1007/s12124-015-9322-6

Tharp, R. G., \& O'Donell, C. R. (2016). Cultural-historical activity theory and cultural community psychology: The potential for greater commonality. Mind, Culture, and Activity, 23(1), 5-14. http://dx .doi.org/10.1080/10749039.2015.1107742

Tomasello, M. (Ed.). (1998). The new psychology of language: Cognitive and functional approaches to language structure. Mahwah, NJ: Lawrence Erlbaum.

Toomela, A. (2000). Activity Theory is a dead end for cultural-historical psychology. Culture and Psychology, 6(3), 353-364. http ://dx.doi.org/10.1177/1354067X0063005

Tulviste, P. (1991). The cultural-historical development of verbal thinking. Commack, NY: Nova Science Publishers.

Valsiner, J. (2009). Cultural psychology today: Innovations and oversights. Culture $\mathcal{B}$
Psychology, 15(1), 5-39. https://doi.org/10.1 177/1354067X08101427

Valsiner, J. (2014a). An invitation to cultural psychology. London: Sage.

Valsiner, J. (2014b). Needed for cultural psychology: Methodology in a new key. Culture ES Psychology, 20(1), 3-30. https://d oi.org/10.1177/1354067X13515941

Valsiner, J. (2014c). What cultural psychologies need: Generalizing theories! Culture $\mathfrak{B}$ Psychology, 20(2), 147-159. https://doi.org/ 10.1177/1354067X14527841

Vygotsky, L. S. (1981). The genesis of higher mental functions. In J. V. Wertsch (Ed.), The concept of activity in Soviet psychology (pp. 144-188). Armonk, NY: M. E. Sharpe Inc.

Vygotsky, L. S. (1986). Thought and Language. Cambridge: The Mit Press.

Vygotsky, L. S. (1987). The collected works of L. S. Vygotsky: Problems of general psychology (Vol. 1). New York, NY: Plenum Press.

Wertsch, J. V. (Ed.) (1981). The concept of activity in Soviet psychology. Armonk, NY: M. E. Sharpe Inc.

Wertsch, J. V. (1998). Mind as action. New York, NY: Oxford University Press.

Yanchar, S. C., \& Westerman, M. A. (2006). Reconsidering qualitative research approaches: New interpretations and future possibilities. New Ideas in Psychology, 24(3), 187-188. http://dx.doi.org/10.1016/j.newid eapsych.2006.09.003

Zinchenko, V. P. (1997). La psicología sociocultural y la teoría psicológica de la actividad: revisión y proyección al futuro. In J. V. Wertsch, P. del Río \& A. Álvarez (Eds.), La mente socio-cultural. Aproximaciones teóricas y aplicadas (pp. 35-48). Madrid: Fundación Infancia y Aprendizaje.

Zittoun, T. (2014). Three dimensions of dialogical movement. New Ideas in Psychology, 32, 99-106. http://dx.doi.org/10 $.1016 /$ j.newideapsych.2013.05.006

Zittoun, T. (2018). A lesson in dialogical thinking [Review of the book The dialogical mind: Common sense and ethics, by Ivana Marková]. Culture Ė Psychology, 24(1), 
107-121. https://doi.org/10.1177/1354067 X17701272

\section{Notes}

* Research article.

i Our notion of activity is not limited to Leont'ev (1979). We also consider Wertsch's (1985) contribution to this concept. For us, Wertsch's notion of activity may help to overcome the "dead end" that activity theory represents for some theorists (Toomela, 2000; Tharp, \& O’Donell, 2016). According to Wertsch, an activity or activity setting refers to a socio-culturally defined context in which human mental functioning takes place. The setting is, to a great extent, an interpretation of the participants. Any activity setting is, then, based on a set of implicit assumptions about the aspects which are necessary for this context to exist and be recognised by the participants. In this sense, the notion of practice (Lave, 1988, 1993, Lave \& Wenger, 1991) and the notion of activity setting $(1991,1998)$ are so close.

ii The genetic approach defended by Wundt and all the German tradition, among others, as well as by Vygotsky and HistoricalCultural Psychology has become a key piece in the methodological proposals of Cultural Psychology. In fact, authors like Cole, Boesch, Bruner, Eckensberger or Shweder defend the need of adopting a developmental or genetic approach. Thus, they focus their analysis on the processes of development, not because they are interested in these processes in themselves, but because they consider this analysis unavoidable for understanding psychological processes (Boesch, 1996; Bruner, 1990; Shweder, 1990; Eckensberger, 1996; Wertsch, 2000).

iii It is important to take into account that the theorists included in the symbolic approach share or are in a way are inheritors of Taylor's idea of meaning. This author stresses that meaning and significance do not only refer to representation (which leads us to a mentalist view), but also to that which is meaningful or important for human life.

iv Although Vygotsky did not explicitly elaborate a theory centered on activity, many authors claim that he was very close to that (Cole 1996; Kozulin, 1986; Wertsch, 1981, Zinchenko, 1997). Issues such as the dialogic, non-reductionistic, social, historical and mediated character of mental functions as well as his active conception of subjects are among the arguments that these authors use to support this claim.

v Cole adopts Ilenkov's notion of an artifact. This notion accounts for ideal phenomena (meaning and value). However, by using this term, Cole does not pay special attention to ideal artifacts, as meaning. He focuses on the general role that artifacts play in the configuration of culture. 